Claudia E. Suter*

\title{
Classifying Iron Age Levantine Ivories: Impracticalities and a New Approach
}

\author{
DOI 10.1515/aofo-2015-0007
}

\begin{abstract}
For more than a century scholarship has focused on the stylistic classification of Iron Age Levantine ivory carvings with the aim of specifying centers of production and their time of activity. With nearly all ivories from Nimrud published, the difficulties in attaining a generally accepted classification have increased rather than diminished. One could say that we have reached a deadlock. This contribution outlines the problems that the author encountered in her research on the Samaria ivories, the largest assemblage from a Levantine capital. It promotes Marian Feldman's new sociological approach, which provides a convincing theoretical framework for explaining why the present classification endeavors are impractical.
\end{abstract}

Keywords: Levant, Iron Age, Ivory Carving, Style, Classification, Connoisseurship, Social Practices

\section{Challenges with the Samaria Ivories Project}

In 2001, at the exploratory workshop on Eastern Mediterranean art of the $1^{\text {st }}$ millennium BCE held in Fribourg, Christoph Uehlinger lamented the poor publication of the Samaria ivories. They form not only the most substantial art collection from Iron Age II Israel, but also the largest assemblage of Levantine ivories of that time that came to light in a Levantine capital. Their publication dates from 1938, comprises roughly 200 items of a corpus that was long estimated to comprise 500-600 pieces, and lacks a proper catalogue (Crowfoot / Crowfoot 1938). The workshop participants, including several ivory specialists (Annie Caubet, Georgina Herrmann, Irene Winter), applauded Uehlinger's idea of launching a project to remedy this situation. I was entrusted with the re-assessment of the Samaria ivories based on a proper and complete catalogue of the entire assemblage. This offered me an opportunity to return, after many years' dedication to $3^{\text {rd }}$ millennium BCE Mesopotamia, to $1^{\text {st }}$ millennium BCE material that I had studied in my MA thesis.

As a biblical scholar of Othmar Keel's Fribourg School, Uehlinger's interest in the Samaria ivories is obvious. The Fribourg School endeavors to give voice to material remains, especially that including figurative imagery, as a corrective to the text of the Bible in the writing of Israel's and Judah's histories. Due to biblical prejudice, the Samaria ivories had long been excluded from Israel's cultural legacy. I quote the ivory specialist Richard Barnett (1982: 49): “As Ahab’s queen Jezebel was a Phoenician, it is more than tempting to conclude that the hoard formed part of the pagan cult material of ivory which she is known to have introduced." Goals of my project were, therefore, to rehabilitate the Samaria ivories to the glory of Israel, explore local production, and further the thorny stylistic classification of Iron Age Levantine ivories based on the most substantial assemblage that came to light in a Levantine capital. Uehlinger was confident that once the Samaria material was properly catalogued, local artisanship, i.e. locally made ivory groups, could be identified not only at Samaria, but also across the larger corpus of Levantine ivories (Uehlinger 2005).

With the above-mentioned estimate of 500-600 pieces in total, my project was scheduled to be completed in two to three years. The first excitement surfaced in storage rooms when the full extent of the assemblage turned out to number about 12,000 pieces, with the vast majority being very small fragments. In the field, this large quantity of fragments was registered in groups rather than individually. These groups were then rearranged for study purposes before handed over to seven different institutions on three different continents, which registered the fragments in different groupings. The preparation of a catalogue according

*Corresponding author: Claudia E. Suter, Universität Bern, Institut für Archäologische Wissenschaften, Abteilung für Vorderasiatische Archäologie, Länggassstrasse 10, CH-3012 Bern, Switzerland, E-Mail: claudia.suter@iaw.unibe.ch 
to current standards thus became a nightmare of tediousness, the two major challenges being to match field and museum numbers and create manageable, sensible new groupings. Cataloguing individual pieces with this amount of fragmented material is not feasible: it would not only have been disproportional, but also a major source of mistakes.

A further challenge cropped up with the in-depth study of my comparative material. Only by comparison with more complete ivory carvings from other sites, can one get an idea of the collection's original look and splendor. Thus my assessment of the fragmentary assemblage from Samaria, including identification of carving techniques, fixing techniques, and imagery, and assigning the assemblage a place within the Levantine corpus, required an understanding of the entire corpus of Levantine Iron Age ivory carvings. This very large corpus comprises over 6,000 pieces from Nimrud and hundreds of other finds found dispersed over the Near East and the Mediterranean. The study of this material is much facilitated by the rigorous publication of Ivories from Nimrud (IN in the following), initiated by Max Mallowan and near to completion thanks to a lifetime's dedication to it by Georgina Herrmann.

Reading through the IN volumes, however, it soon became apparent that the present stylistic classification is not convincing: it does not encompass the entire corpus; the definition of groups is debatable and methodologically problematic; style is often confused with iconography; groups blend into one another, with many pieces that do not fit in; the classification is inconsistent in that identified groupings are morphing over time as well as in individual scholars' perceptions; and, most importantly, the underlying premise about local styles does not fit the socio-political situation of the Iron Age Levant.

Initially I had the ambition of probing a new and comprehensive classification. But the more I was looking at the ivory carvings from the perspective of style in the course of this exercise, the more my undertaking proved doomed to fail. My disheartenment with the project - the immense amount of Samaria ivories making every step of work seem insurmountable, its fragmentation leaving many questions in the description of the objects unanswerable, and the impracticality of classifying the comparative material - led to repeated interruptions of work in favor of short-term projects with restricted deadlines. In the meantime, Marian Feldman independently reached similar conclusions concerning the present stylistic classification. Her expertise in and fascination with luxury objects led her to develop a theoretical framework for understanding the impracticality of a stylistic classification of this material (Feldman 2014).

\section{Problems in the Stylistic Classification of Levantine Iron Age Ivories}

Let's take a step back. Iron Age Levantine ivories were found in an area stretching from Iran in the east to Spain in the west (Winter 1976a: figs. 1-2; Niemeyer 2004: fig. 3; Herrmann 2008: fig. 27g). The vast majority of these luxurious prestige objects were taken as booty or tribute by Assyrian kings in the course of their successive incorporation of the Levantine states into their empire. Over 6,000 pieces came to light in Nimrud, capital of the Assyrian empire in the $9^{\text {th }}$ and $8^{\text {th }}$ centuries BCE. Most of the other sites produced much smaller assemblages, often only scattered finds, that arrived there by complex ways I cannot explore here; just to say that Levantine ivory carvings were not merchandise as had long been assumed.

The find circumstances, together with archaeologists' traditional commitment to style for connecting artifacts to their times and places of manufacture, led scholars focus for a century on stylistic classification. The history of research regarding this stylistic classification has recently been summarized from different angles by Herrmann (Herrmann / Laidlaw 2009: 53-57), Di Paolo (2009: 136-141), Wicke (2009: 239-246), and Feldman (2014: 13-18). Here I will only add a few points that have not yet sufficiently been made clear.

First, the paradox should be mentioned that Levantine ivories of the Iron Age are often studied by Mesopotamian rather than Levantine specialists, myself included. This is, of course, related to the fact that the vast majority was excavated in Nimrud and other Assyrian capitals. Moreover, Levantine archaeology tends to center on fieldwork with only few colleagues with a passion for art. A further impediment resides in the fact that Levantine art incorporates influences from Egypt, Anatolia, Mesopotamia, and the Aegean. Its study thus requires knowledge of four distinct artistic traditions that today tend to be studied by separate specialists. 
Second, I would distinguish two phases of quite different approaches to the stylistic classification of Levantine ivories of the Iron Age. From 1912-1981, scholars, including Frederik Poulsen (1912), Richard Barnett (1957), and Irene Winter (1975; 1976a; 1976b; 1981), attempted to group the pieces of the then known corpus into two to three regional styles. By contrast, Georgina Herrmann, who subsequently published four volumes of Nimrud ivories (Herrmann 1986; 1992; Herrmann / Laidlaw 2009; 2013), began a reversed approach from bottom-up. She advocates moving from identifying "sets" of panels similar in size, shape, subject, style, framing and method of fixing, to arranging them into larger "groupings or style-groups" based on a range of technical and stylistic criteria, to finally attributing such "style-groups" to one of three Levantine "traditions" based on variations in iconographical details, technical features, and fitters' marks (Herrmann 2005; Herrmann / Laidlaw 2009: 56-68).

This change in approach may have become feasible as the material grew in quantity in "an attempt to impose order on this mass of material" (Herrmann / Laidlaw 2009: 56). However, it led to a plethora of small groupings (Fig. 1), while tuning out large parts of the corpus, namely innumerous pieces that do not fit into these small groupings. More significantly, this approach imposed a number of premises that have not been made sufficiently explicit. First, regional styles became traditions, which presupposes continuity from an earlier time and is not necessarily restricted to style. ${ }^{1}$ Second, the conflation of style-groups with "workshops" or "schools," which are then sought in specific Levantine cities, presupposes that local styles would have been the norm. Although problems of terminology have extensively been discussed in the above-mentioned exploratory workshop (Suter 2005), no general agreement was reached, and the workshop took place before the last two IN volumes were published. Apparently time was not yet ripe to grasp the consequences of the new premises implied in the changed approach.

The stylistic homogeneity of many of Herrmann's groups is debatable, as Irene Winter (1992; 1998) noted in her reviews to IN 4-5. Herrmann is not to blame for the difficulties in isolating clear-cut stylistic groupings as will become evident below. Her own struggles with the material in the way in which she chose to approach it becomes obvious in the changes she made herself over the four IN volumes published between 1986 and 2013 (Table 1). She not only repeatedly renamed her traditions, but also abandoned many of her style-groups or changed their formation and/or their assignment to a tradition. ${ }^{2}$ Unfortunately, she did not always make her changes explicit enough. To add to the confusion, scholars following in her footsteps often adopt her style-group labels for changed groupings. ${ }^{3}$ These intricate details are nearly impossible to grasp for anyone who does not dedicate much time to a tedious scrutinizing of the relevant publications. Thus it can happen that scholars less familiar with ivories loose orientation. ${ }^{4}$ In the most recent IN volume, Herrmann (Herrmann / Laidlaw 2013) has thankfully included plates that, for the first time, illustrate and visualize the discussion of stylistic groupings.

\footnotetext{
1 Winter (1992: 138-139) noticed the avoidance of style as a diagnostic.

2 Note that changes in the formation of groups are not visible in Table 1.

3 Compare, for example, the changing formation of the Wig-and-Wing group, which evolved out of the Pointed-Ear Group in combination with previously unassigned pieces, in Herrmann (1986: 14; 1992a: 30 note 52; Herrmann / Laidlaw 2009: 83-84; 2013: 93), Wicke (1999: 811, 814, 833; 2013: 557-558), and Scigliuzzo (2005; 2009); or that of the Roundcheecked-and-Ringletted group in Herrmann (1986: 19, 28; Hermann / Laidlaw 2009: 99; 2013: 110) and Wicke (2005).

4 In Ann Gunter's discussion of ivories, two of the four illustrations meant to visualize typical examples of different "traditions" are atypical: that of a Phoenician ivory shows a typical Wig-and-Wing panel (Gunter 2009: fig. 30 = Herrmann / Laidlaw 2009: no. 99), and that of a North Syrian Flame-and-Frond ivory shows a hotly debated panel, which I would attribute to the South Syrian group, just like the former (Gunter 2009: fig. 32 = Herrmann 1992: no. 456). For the former, see Scigliuzzo (2005: 572-575), and Herrmann / Laidlaw (2013: 93); for the debate on the latter, see Winter (1998: 152), Wicke (2009: 256-257), and Herrmann / Laidlaw (2009: 95, 2013: 109).
} 


\section{Provisional division of ivory style-groups}

(thanks 10 G. Herrmann, I.J. Winter, E. GubeL, D. Wicke et al.; "exploratory suzgestions)

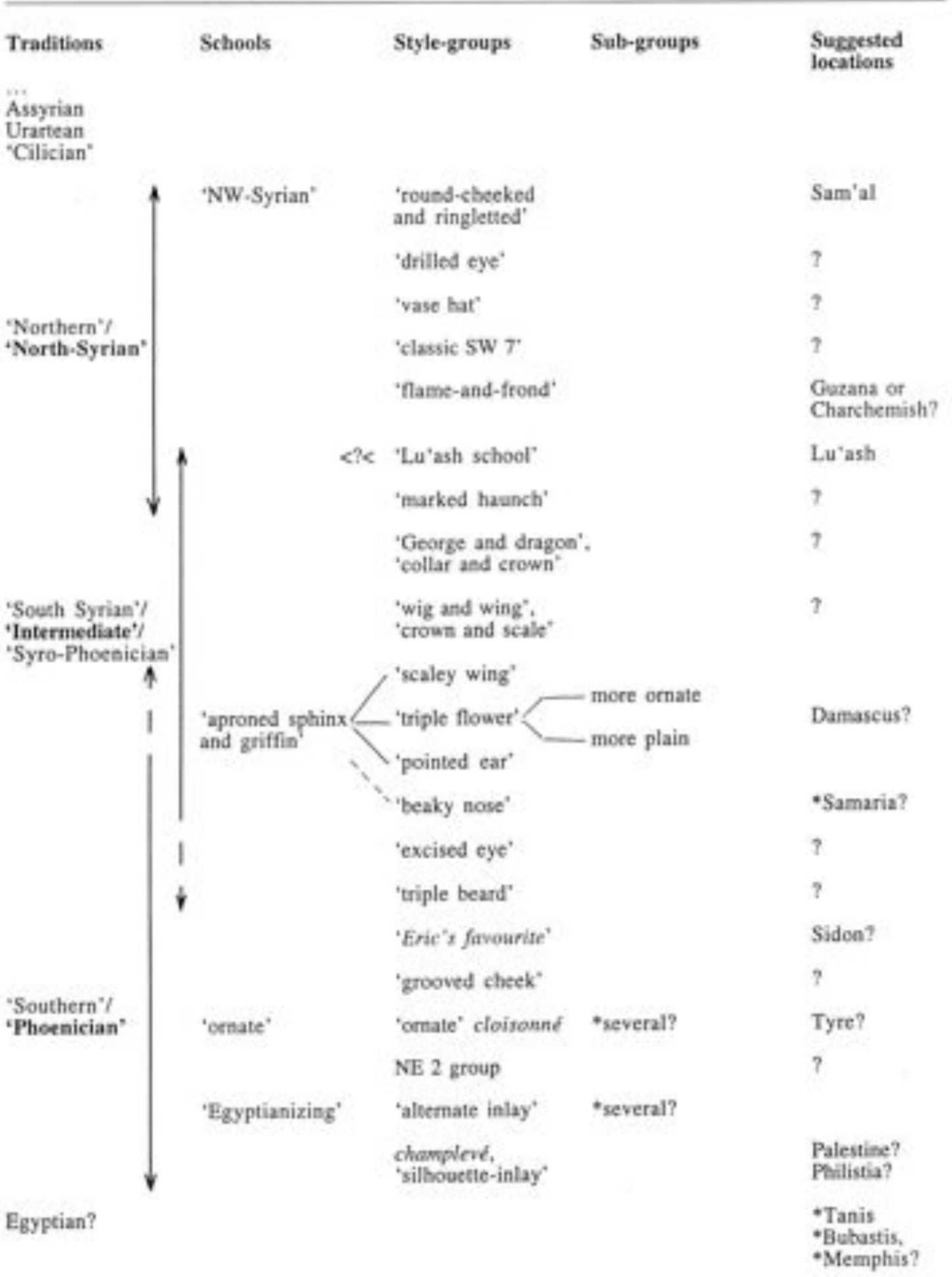

Fig. 1: Handout prepared by Christoph Uehlinger for the Fribourg Exploratory Workshop in 2001. Courtesy of Christoph Uehlinger. 
Table 1: Style-groups and attributions as proposed over the course of Ivories from Nimrud 4-7 (1986-2013).

\begin{tabular}{|c|c|c|c|}
\hline IN 4 (1986) & IN 5 (1992) & IN 6 (2009) & IN 7 (2013) \\
\hline Northern Tradition & North Syrian & North Syrian & North Syrian \\
\hline Flame\&Frond & Flame\&Frond & Flame\&Frond & Flame\&Frond \\
\hline Drilled-Eye & Drilled-Eye & & Animal-Contest Scenes \\
\hline SW7-Chairbacks & & & SW7-Chairbacks \\
\hline Roundcheecked\&Ringletted & Roundcheecked\&Ringletted & Roundcheecked\&Ringletted & Roundcheecked\&Ringletted \\
\hline \multicolumn{4}{|l|}{ Burnt-Palace } \\
\hline Intermediate & Intermediate & Syrian & Syrian-Intermediate \\
\hline Beaky-Nose & & Beaky-Nose & Beaky-Nose \\
\hline Lu’ash & Wig\&Wing & Wig\&Wing & Wig\&Wing \\
\hline \multirow[t]{2}{*}{ George\&Dragon } & Crown\&Scale (+Scaly-Wing) & Crown\&Scale & Crown\&Scale \\
\hline & $\begin{array}{l}\text { Collar\&Crown } \\
\text { (+Sharply-Curved-Collar) }\end{array}$ & & Tall-Crown \\
\hline \multicolumn{4}{|l|}{ NW-Palace } \\
\hline \multirow[t]{4}{*}{ Haunch-Markings } & Finely-Carved & & \\
\hline & Large\&Thin-Panels & & \\
\hline & NW21-cows\&stags & & \\
\hline & $\begin{array}{l}\text { S10-cows\&stags } \\
\text { (+Excised-Eye) }\end{array}$ & & \\
\hline Southern Tradition & Phoenician & Classic Phoenician & Phoenician I \\
\hline Egyptianizing & Egyptianizing & Egyptianizing & Egyptianizing \\
\hline $\begin{array}{l}\text { Ornate } \\
\text { Champlevé } \\
\text { Gowned-Ladies } \\
\text { Long-Sphinx-Panels } \\
\text { Openwork-Cloisonné-Panels } \\
\text { Unusually-Shaped-Panels }\end{array}$ & $\begin{array}{l}\text { Ornate (+Triple-Flower) } \\
\text { Samaria School of Champlevé }\end{array}$ & Ornate & $\begin{array}{l}\text { Ornate } \\
\text { Ornate-Modelled-Panels } \\
\text { (Triple-Flower) } \\
\text { Champlevé-Plaques\&Panels } \\
\text { 3-sided-Furniture-Fittings } \\
\text { Pharaoh-Statuettes } \\
\text { (+NE2+NW-Palace) } \\
\text { Unusually-Shaped-Ivories } \\
\text { Finely-Carved }\end{array}$ \\
\hline \multirow[t]{6}{*}{$\begin{array}{l}\text { Aproned-Sphinx\&Griffin } \\
\text { Excised-Eye } \\
\text { Pointed-Ear } \\
\text { Scaly-Wing } \\
\text { Sharply-Curved-Collar } \\
\text { Triple-Flower } \\
\text { Plaques }\end{array}$} & NE2 & Group2-Bridle-Harness & Group2-Bridle-Harness \\
\hline & & Other Phoenician & Phoenician II \\
\hline & & Group1-Bridle-Harness & People (+Crinkly-Hair) \\
\hline & & 3-sided-Furniture-Fittings & $\begin{array}{l}\text { Sphinxes-Griffins\&Stylized- } \\
\text { Trees }\end{array}$ \\
\hline & & & Bovids\&Cervids \\
\hline & & & $\begin{array}{l}\text { Small-Objects (+Group1-Bridle- } \\
\text { Harness+Plaques) }\end{array}$ \\
\hline
\end{tabular}


Third, in the relabeling of the South Syrian regional style defined by Winter (1981) into "Intermediate Tradition," it has gone unnoticed that the ivory carvings assigned to these groups by the two scholars do not exactly correspond. Of course, more Nimrud ivories have become available and Herrmann (1986) concentrated on this new material in IN 4, in which she introduced the term. Nevertheless, while Winter's grouping, revolving around the assemblage from Arslan Tash, was stylistically homogenous within the frame of, or under the presumption of, a regional style, Herrmann's Intermediate group lost stylistic homogeneity. In a follow-up to the Fribourg workshop in Pisa, Dirk Wicke (2009) proposed to abolish the Intermediate Tradition because it did not represent a tradition and had become a wastebasket for pieces that defied attribution to either the North Syrian or Phoenician regional style/tradition. I believe that it was the implications of each term in the new label "Intermediate Tradition" that resulted in an ill-defined stylistic group.

In the last two IN volumes, Herrmann (Herrmann / Laidlaw 2009; 2013), no doubt in response to Wicke, reassigns many "Intermediate" ivories to a "non-classical Phoenician Tradition," although she retains also a "Syrian(-Intermediate) Tradition." Note the renewed change of labels from IN 6-7, which bespeaks "slippery identities" (Feldman 2014: 36-38). By contrast, Wicke (2010: 57-60; 2013), in two recent surveys of Iron Age ivory carvings, speaks only of two Levantine traditions, namely North Syrian and what he infelicitously terms "Levantine," meaning what is generally called Phoenician. ${ }^{5}$

The majority of the Samaria ivories that preserve enough of the design for stylistic analysis would fall within the South Syrian group as defined by Winter. When I was probing an alternative stylistic classification of Levantine ivories because the present one neither convinced me nor incorporated the entire material, I first attempted to go back to three regional styles (Suter 2010). Even if not all ivories can easily be assigned a place within this three-tiered classification, it is, nevertheless, possible to recognize typical "Phoenician," "North Syrian" and "South Syrian" pieces (Fig. 2-5). With Mario Liverani's distinction between ethnic states and city-states, I thought that I could define South Syrian as a regional style, comprising Aram, Israel, Ammon, and Moab, and explain its lack of tradition with the fact that these "ethnic" states descended to a large degree from pastoral nomads. This would have explained the combination of Phoenician and North Syrian elements, imitations of different prototypes, and often certain clumsiness in execution.

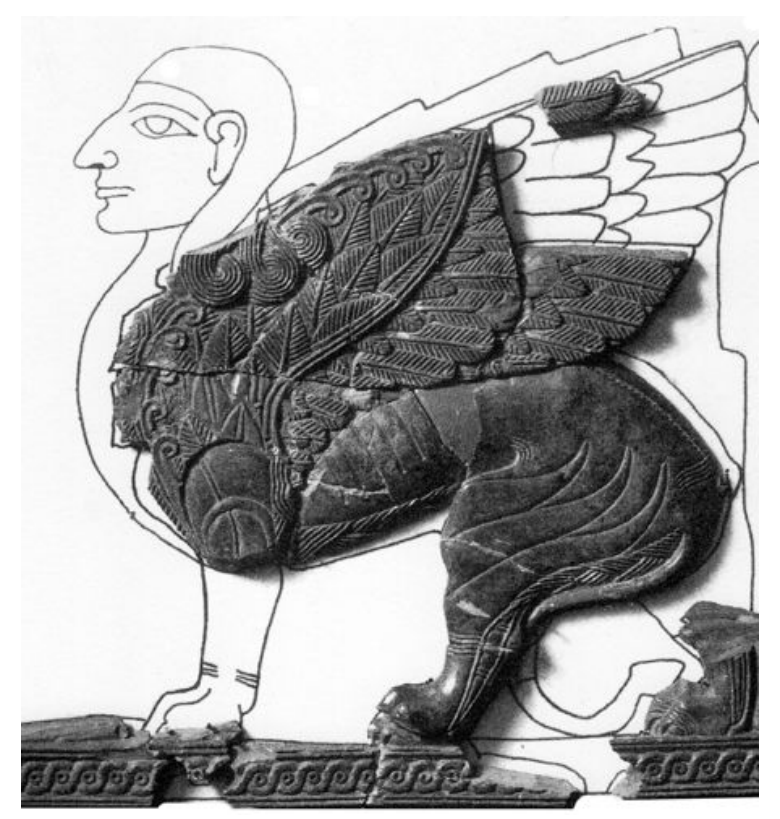

Fig. 2: "North-Syrian" sphinx from Ḥamāh, $10 \mathrm{~cm}$ high. Detail reproduced at 2: 3 after Buhl / Riis (1990: fig. 118 no. 988); courtesy of the National Museum of Denmark.

5 Although many would agree that Phoenician is a problematic term, Levantine cannot be an option, since the Levant encompasses also large parts of North Syria. Herrmann (Herrmann / Laidlaw 2009: 56) opines that the term Levantine "remains a useful term to cover all the ivories originating in the west," i.e. from an Assyrian perspective. For a definition, see Feldman (2014:3-4). 


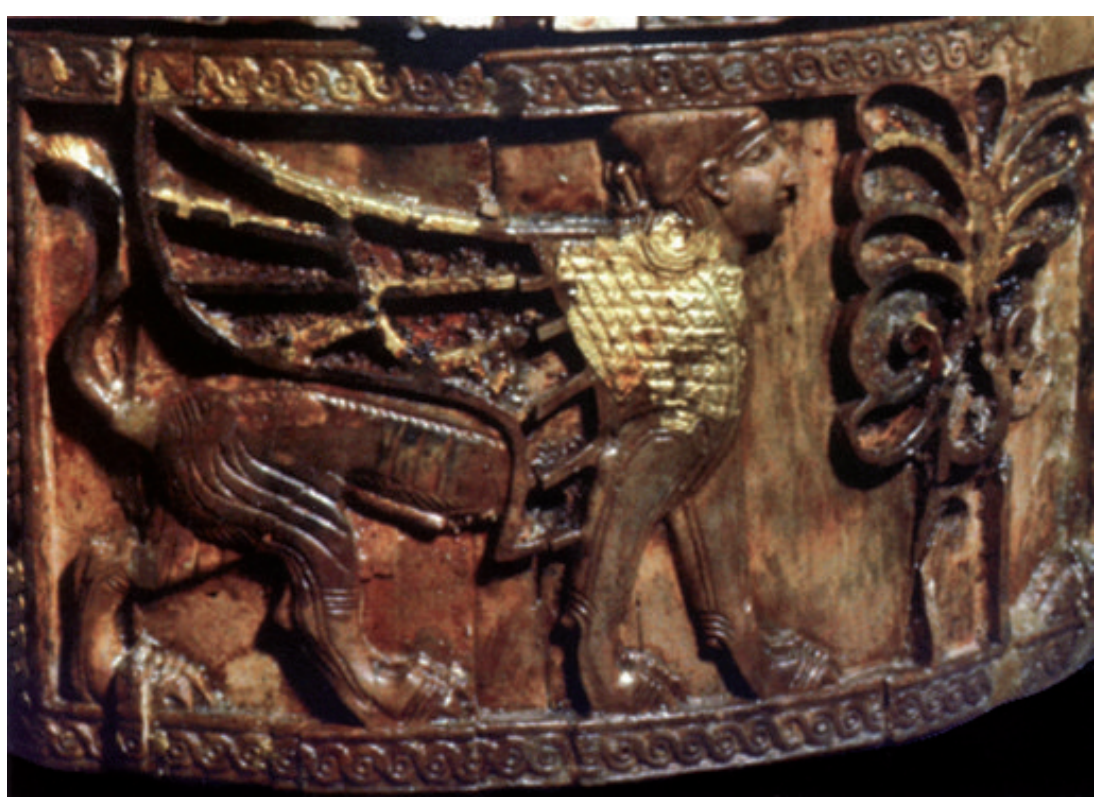

Fig. 3: "North-Syrian” sphinx from Nimrud, $10 \mathrm{~cm}$ high. Detail reproduced at 2: 3 after Herrmann / Laidlaw (2009: pl. I no. 233); courtesy of Georgina Herrmann.

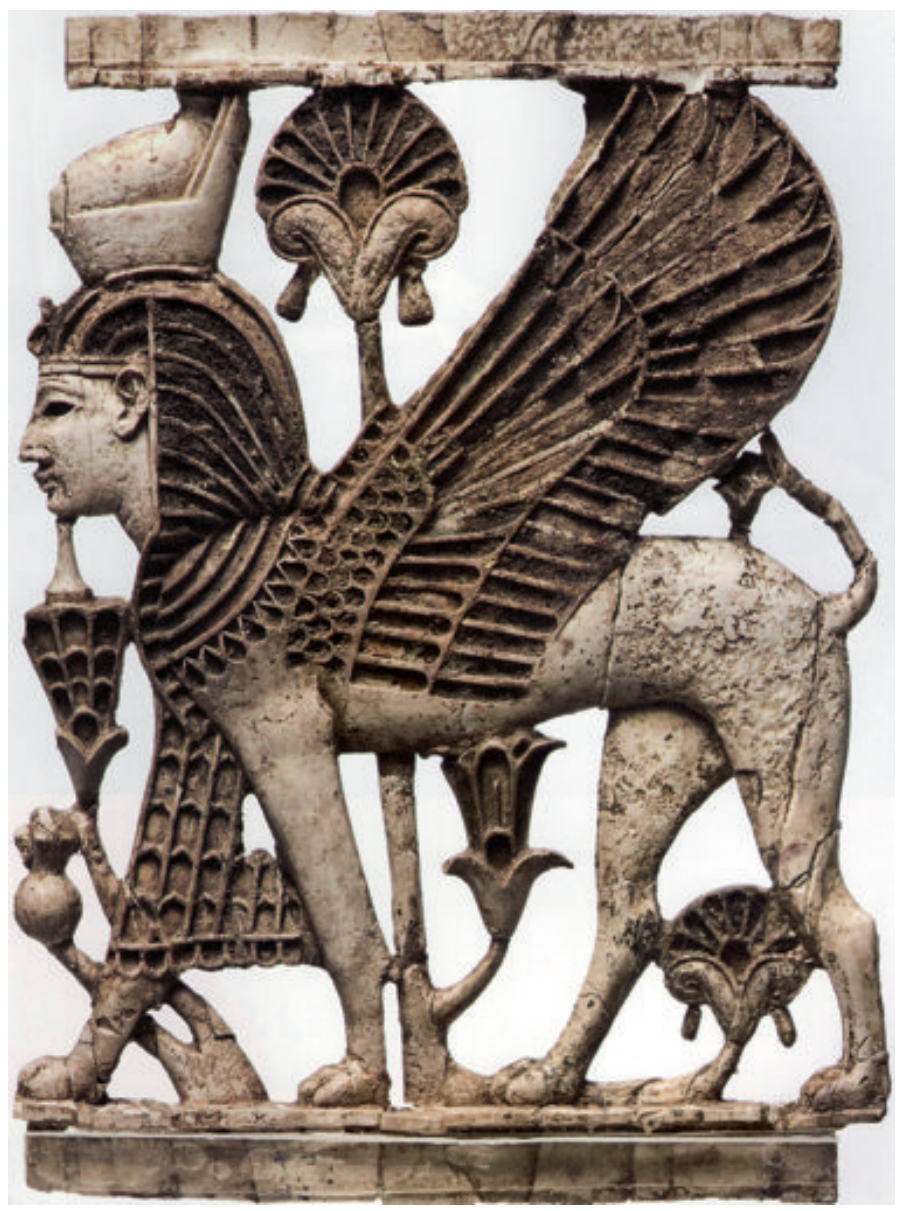

Fig. 4: "Phoenician" sphinx from Salamis, $16 \mathrm{~cm}$ high. Reproduced at 2: 3 after Karageorghis (1973: pl. B no. 258); courtesy of the Department of Antiquities, Cyprus. 


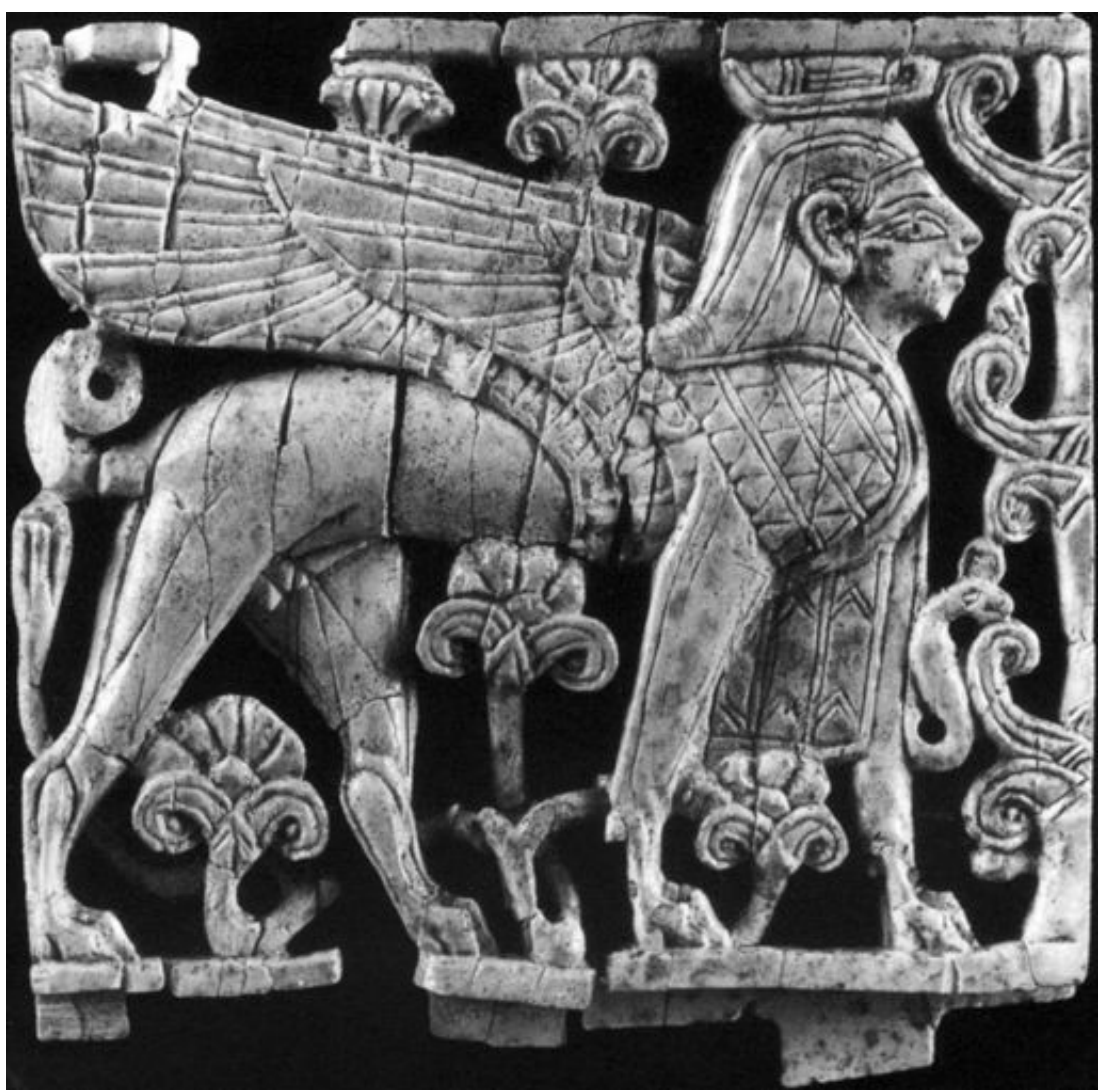

Fig. 5: "South Syrian” sphinx from Nimrud, $7.6 \mathrm{~cm}$ high. Reproduced at 1: 1 after Herrmann / Laidlaw (2013: pl. 67 no. 283); courtesy of Georgina Herrmann.

However, the South Syrian style-group became proportionally too large by comparison with the North Syrian and Phoenician styles. The differences may in fact be differences in time rather than in space, an issue I will come back to below. Moreover, boundaries also blur between these large groups. Finally, my suggested correlation of a regional style with a set of newly formed states of the early Iron Age lacks persuasive arguments in its support as Carlo Zaccagnini pointed out to me.

In a second go, I abandoned style and probed to classify Levantine ivories from a typological perspective, distinguishing different types of objects. However, this undertaking is not feasible at this time and perhaps not desirable either. On the one hand, too little research has been dedicated to types of objects so far, and many questions remain with regard to panels or plaques, the vast majority of ivory carvings. On the other hand, the resulting groups may not be all that meaningful for organizing the material, since techniques and styles cross-cut object types as far as can be observed at the present state of research.

The classification of Levantine ivories is so tantalizing because there is much more diversity than in the preceding Late Bronze Age (Caubet 2013: 457). Winter (1992: 138) noted that "With the Nimrud ivories, perhaps for the first time in the history of scholarship on the Ancient Near East, we are presented with a corpus large enough and with enough shared properties on the one hand, and distinctive enough on the other, to begin to work out these problems for ourselves," i.e. the problems of attribution studies as practiced for Greek vases, for example. In the Fribourg workshop, she outlined a catalogue of criteria for the definition of group boundaries (Winter 2005: 36-38). However, the suggested analytical enterprises - isolating hand, workshop, locale, region, period - can simply not be undertaken due to too many unknowns on the one hand, and the fact that potential criteria - whether stylistic, iconographical, technical, or typological - crosscut on all levels on the other hand.

There is no evidence external to the ivory carvings themselves with regard to their makers. The ivory trade has left no traces in the archaeological record because ivory carvers do not require special installations; 
rather they work with a few simple, portable tools, probably identical to those of woodcarving (Wicke 2010: 37-40; Feldman 2014: 28). We also lack texts that could give us clues as to their organization: whether they depended on a palace, worked in a bazaar alongside other artisans, or were itinerant; whether they worked in larger or smaller units or alone (on textual sources, see also Di Paolo 2009: 133-134).

Elena Scigliuzzo (2005; 2009) attempted to distinguish different hands in Morellian manner within the so-called Wig-and-Wing Workshop. While she succeeded in refining and amplifying a stylistically homogenous sub-group, I believe it impossible that one can "demonstrate, not merely assert, that a certain variant [within this sub-group] betokens the work of two different hands in the same workshop, as opposed to the work of the same, single individual on different days, or at different stages of a career," questions that Winter (1992: 136-137) posed earlier. The same applies to two other stylistically homogenous sub-groups assigned to the North Syrian style, for which different hands or workshops have been proposed: the SW7-Chairbacks originally isolated by Winter (1976b), and the Roundcheeked-and-Ringletted group as defined by Wicke (2005). ${ }^{6}$

In addition to the lack of evidence regarding ivory carvers, there is hardly any evidence that allows us to locate or date Levantine ivories with any more precision than the Levant from c. 1000-700 BCE, perhaps even a bit longer on each end. Practically all ivory carvings from excavations were discovered in secondary or tertiary contexts. Luxurious prestige goods could have much longer lives than utilitarian objects. The closest comparative material are prestige goods of other materials, such as metal, which are equally difficult to locate or date as the ivories. Immovable art, namely stone sculpture, does not provide reliable anchors for them either, since the direction of influence need not necessarily go from large-scale to small-scale art, but can also go from ivory carving to stone relief (Winter 1989). Moreover, the dating of many sculptures remains uncertain, even if some can be fixed in time based on inscriptions that identify a royal patron whose reign we can date. The traditional classification of stone orthostats, which presumed a linear evolutionary development of style across the northern Levant, has been challenged in recent scholarship in favor of more complexity and diversity (Feldman 2014: 22-26, with further literature). Also Winfried Orthmann (2002; 2013), who devised the classification that was followed for several decades, now sees less coherence than he had originally assumed.

Based on the extant data, it seems virtually impossible to locate ivory carving production or date time of activity. In the absence of external criteria, we are left with the ivory carvings themselves and can only speculate about production models. The model of isolated local workshops presumed by Herrmann is neither supported by the socio-political landscape of the time nor by the material itself.

The Iron Age Levant was composed of a multitude of small kingdoms that competed with each other or fought together for independence against imperialistic Assyria. State boundaries and alliances fluctuated, and the population of these states was heterogeneous. Israel's population, for example, included descendants of Late Bronze Age inhabitants, pastoral groups that settled there during Iron Age I, Aramaeans in the northeast, and Phoenicians on the northern coastal plain (Finkelstein 2013: 109-112). Thus, in spite of a segmented political landscape, we are facing an interconnected world with a high degree of mobility. In such a world, the ethnicity of individual ivory carvers need not have affected their work and, vice versa, several styles could have coexisted in one place (Suter 2010: 996-997). Moreover, luxury goods, in contrast to utilitarian objects, were geared to the elite, which seems to have been supra state oriented; this is suggested by the repertoire of imagery shared across the Levant. I do not mean to categorically exclude the possibility that local styles may occasionally have existed. ${ }^{7}$ I only propose that isolated local styles are highly unlikely to have been the norm.

The simplistic model of one local style per state or city must be abandoned. This is particularly obvious in the case of Herrmann's Flame-and-Frond “workshop,” which she keeps on insisting to locate in Tall Halaf

\footnotetext{
6 For most of the actual pieces of the SW7-Chairbacks group, see Mallowan / Herrmann (1974); for discussions of the group, Winter (1976c), Herrmann (1996: 156-58), and Herrmann / Laidlaw (2013: 111). On the Roundcheeked-and-Ringletted group, see the literature cited in note 4 above.

7 I see potential candidates in the small Roundcheeked-and-Ringletted group (Wicke 2005), or the even smaller group of Provincial-Style-Figures (Herrmann 1986: 187-189; Herrmann / Laidlaw 2013: 263-265; Wicke 2013: 559 note 19).
} 
(Herrmann / Laidlaw 2013: 95-100), despite of repeated voices of dissent (Winter 1998: 150-151; Affanni 2009; Mazzoni 2009). The large grouping assembled under the label Flame-and-Frond is characterized by distinct markings incised on animal bodies that render muscles, tendons, bone structures, feathers, and manes in stylized form; particularly leaping to the eye are flame-shaped markings for muscles on hind legs. ${ }^{8}$ Such markings also occur on other objects, both prestige items made of metal or stone, and large-scale stone sculpture. The grouping of ivories and other objects with these markings is not stylistically homogenous, and certainly not sufficiently distinct for a local style. Most scholars today agree that Flame-and-Frond ivories were not made in one "workshop," but all over the northern Levant (Affanni 2009; Feldman 2012; 2014: 5257; Wicke 2013: 363-364; Mazzoni 2014: 691).

Other groupings that Herrmann maintained over the last four IN volumes are not clearly demarcated. Two examples of groupings that blend into one another and in which individual group members have been moved back and forth between the groups are the Egyptianizing and Ornate groups on the one hand, and the Wig-and-Wing and Crown-and-Scale groups on the other. Moreover, there are noticeable differences in quality among these groups that seem to betray different grades of artisanal skill. Such differences concern not only the intricacy of the design, but also elegance and refinement in execution. ${ }^{9}$ Some differences between heavily inlaid and non-inlaid Phoenician ivories make one wonder whether the latter are imitations of the former, especially when details of incised design in the latter imitate the shape of cloisons of the former. ${ }^{10}$ Such imitations may have been either made by less skilled artisans or later in time. In the last two IN volumes, newly identified groups, especially within the large Phoenician "tradition," have been assembled not on the basis of stylistic criteria, but rather on the basis of object type or imagery as reflected in their labels (Table 1).

One reason why Iron Age Levantine ivories elude a clear-cut division into rigid groups - whether stylistic, iconographic or typological -, and are thus impossible to classify, is the lack of specialization and standardization. Silvana Di Paolo (2009: 141-144; 2014: 117-118) points out this lack by comparison with ivory manufacture in the Byzantine Empire and early medieval Europe, where large workshops specialized on certain object types and carving techniques and standardized object dimensions and the repertoire of images. Because such products are characteristic of manufacture in workshops, Di Paolo argues that the term workshop borrowed from these cultures with different socio-economic conditions cannot be applied to the Iron Age Levant.

The lack of specialization and standardization can easily be demonstrated; I will point out only some examples. The members of the small group of Three-Sided-Furniture-Fittings (Herrmann / Laidlaw 2013: 3033) differ in size, technique, iconographical details, and intricacy of design; Herrmann suggests that they were made in "more than one centre across the [Phoenician] area." The same can be said about the members of the Unusually-Shaped-Ivories (ibid.: 40-43), which Herrmann sees as "straddling the 'boundary' between the Egyptianizing and Ornate Group." Also other types of objects, such as pyxides, palettes, fan handles, horse trappings, or figures carved in the round, do not form homogenous groups. In fact, there are no standardized object types. Nor are there specialized carving or fixing techniques confined to single groups. Different carving techniques can be combined on the same object. Combinations include open and solid relief; champlevé and cloisonné; solid relief and cloisonné; openwork relief and cloisonné; carving in the round and incision; cloisonné and incision; cloisonné, incision, and carving (nearly) in the round. ${ }^{11}$ The "pegged" inlays ascribed to North Syria as opposed to glued inlays ascribed to Phoenicia are not confined to specific "workshop" groups. Similarly, there are no motifs confined to a single "workshop" group.

8 For recent descriptions of the features, see Wicke (2013: 553 note 17), and Feldman (2014: 52).

9 Within the Egyptianizing group, compare IV 995 and IV 1006 with the rest of panels on Herrmann / Laidlaw (2013: 29 fig. 2b); within the Ornate group, compare V 496, V 480, IV 1086, and VII 103 with the other panels on ibid.: 36 fig. 2 h, or IV 1107 and IV 12 on the following fig. $2 \mathrm{i}$.

10 Compare, for example, the relief sphinx Herrmann (1992: nos. 127-128) with the cloisonné sphinxes Herrmann (1986: nos. 1010-1012), or the relief sphinx Herrmann (1986: no. 655) with the cloisonné sphinxes Herrmann (1986: no. 1012), and Karageorghis (1973: nos. 318/298).

11 For just a few examples, see Herrmann (1986: nos. 1163, 1165); Herrmann / Laidlaw (2009: nos. 146, 233-237, 275, 276, 279, 280, 287, 289, 353, 356, TW20); Herrmann / Laidlaw (2013: nos. 472, 608). 


\section{A New Sociological Approach}

Marian Feldman (2012; 2014) found a powerful theoretical framework that can explain the impracticality of classifying Iron Age Levantine ivories and make sense of their typological and stylistic diversity with paradoxically crosscutting features that blur boundaries on all levels. Shifting attention away from connoisseurial attributional endeavors, which can only lead to improvable hypotheses, Feldman approaches stylistic specificities of Iron Age Levantine ivories from a social perspective through the lens of Pierre Bourdieu's theory of practice.

Attempts to attribute ivories to specific locales rely on art historical connoisseurship (Ebitz 1988; Neer 2005). This method was developed by Giovanni Morelli for the study of Italian Renaissance painting in the spirit of $19^{\text {th }}$ century nationalism and refined by Bernard Berenson to become a pillar of $20^{\text {th }}$ century art history. Its best-known application to ancient art is doubtlessly John Beazley's Attic Red-figure Vase-painters. As Feldman (2014: 18-26) shows, this method cannot work for Iron Age Levantine ivories, not only because of the lack of documented artists and other information concerning the socio-economic context of production, but also because of a circularity of argument within its nature. The connoisseurial method calls for primacy of evidence from the works themselves. Yet, this is impossible to carry out to its end. When external information is available to confirm an attribution, the connoisseurial exercise is redundant; when it does not exist, the attribution can never be proven (ibid.: 36).

Key concepts of Bourdieu's work are cultural capital, habitus, and field. Bourdieu extends Carl Marx's idea of capital beyond the economic into the more symbolic realm of culture. Cultural capital refers to skills, tastes, posture, clothing, mannerisms, etc. that one acquires through being part of a particular social class. Sharing similar cultural capital creates a sense of collective identity. Habitus refers to the physical embodiment of cultural capital, i.e. deeply ingrained habits, skills, and dispositions that one possesses due to one's life experiences. In Le sens pratique, Bourdieu (1990) argues that social agents do not calculate according to rational criteria, but operate according to an implicit practical sense and bodily dispositions, according to "a feel for the game." While "feel" corresponds to habitus, "game" corresponds to field, referring to various distinct, though sometimes overlapping, arenas of practice, such as art, education, religion, law, etc. With the habitus, Bourdieu solves the notorious antinomy between objectivism and subjectivism and finds a middle ground between structuralism and phenomenology.

Feldman's innovative application of Bourdieu's theory of practice to style in art allows her to explore artistic style as a social player in community formation. As a case study, she chose the incised animal markings that Herrmann sees as characteristic of her above-described Flame-and-Frond group (ibid.: 43-78). Feldman's definition of style is at the level of the minutiae that connoisseurial pursuits would interpret as unintentional signature elements of artistic identity (ibid.: 44). Feldman, however, perceives the animal markings as revealing practices of doing that engender pan-regional collective identity, along the lines of Bourdieu's habitus (ibid.: 57). She reverses the vantage point from Bourdieu's perspective of the person who already participates in a habitus to that of the participation in the habitus that inculcates various doxa to the point that they become self-evident to the person. This allows her to "move from the assemblage of objects produced by the practices of a habitus to a clearer sense of the networks and communities of people embedded within it," and to conceive of "multiple intersecting and overlapping networks of skilled artistic practices" (ibid.: 40, 59).

From this perspective, the paradoxically blurred boundaries of stylistic, typological, and technical features in Iron Age Levantine ivories and other prestige objects can be interpreted as a result of the creation of communities around them that crisscrossed the entire Levant (ibid.: 59). Communities of people could move among different polities, while sharing a habitus (ibid.: 41, 59-60). Feldman does not question stylistic groupings in general (ibid.: 40). But, instead of viewing stylistic differentiation as being bound to distinct cities' or states' cultural identities rooted in ethnicity and geography, blood and soil, she proposes to view stylistic differentiation as a result of communities of shared practices that can extend or contract across time and space.

When Feldman speaks of stylistic practices she means not only practices in production, but also practices in consumption. Her approach of addressing style as part of habitus, as a practice, works well because of the 
dual nature of style. Style can be consumed subconsciously despite of having affective properties (ibid.: 6163). It thus parallels Bourdieu's "learned ignorance" that generates a commonsense world, which leads to practices without special awareness. Style thus constitutes community identity rather than simply reflecting it. Since there are degrees of variations of engagement in both production and consumption, we should conceive of "numerous, always shifting communities that emerge and recede as different networks of skilled practices form, change, or break down" (ibid.: 63). In accordance with materiality theories, Feldman views things not as reflecting, signifying or representing, but as being and doing. Thus she understands art both as a "catalyst and glue for community identity" (ibid.: 177).

The animal markings of Feldman's case study were neither invented by Iron Age ivory carvers, nor were they limited to ivory carvings. They go back to Late Bronze prestige objects and also occur on other luxurious objects of the Iron Age, as observed more than fifty years ago by Helene Kantor (1956: 173-174), who identified the "animal style" in North Syrian small-scale art as a direct descendent of Late Bronze Age Levantine crafts. With Bourdieu's sens pratique and habitus, the continuity of animal markings can be understood as part of the logic of stylistic practice within collective memory (Feldman 2014: 64-67). These stylistic practices formed part of a larger scheme aimed at creating a golden age, a heroic past, to hark back to, a scheme that was not restricted to the Levant, but stretched all over the eastern Mediterranean. Wellknown literary manifestations are Homer, Hesiod, and the Bible (ibid.: 73-76). The construction of this golden age "counterbalanced the increasing dominance of commercialism, ethno-linguistic balkanization, and expanding imperialism that characterized the economic and political realities of the time” (ibid.: 75). Luxury art participated not only through material practices of style, but also of motifs, compositions, object types, materials, and technologies.

A most appealing proposal that Feldman makes from her new perspective concerns the shift from geography to time with regard to the traditional larger groupings of Iron Age Levantine ivories. I fully share her suspicion that the stylistic difference between "North Syrian" and "Phoenician" ivories is more likely to be a difference in time than in space. More than thirty years ago, Winter (1976a) suggested to date the flourishing of the North Syrian regional style to the $9-8^{\text {th }}$ centuries and that of the Phoenician to the $8-7^{\text {th }}$ centuries, which has generally been accepted in scholarship. Feldman (2014: 39 with note 133) correctly notes that this suggestion has to be reevaluated given that it was in part based on regionally determined arguments and because of the chronological ambiguity of most archaeological find contexts. But she also notes that there is evidence for a $9^{\text {th }}$ century dating of at least some North Syrian ivories from the Hazael inscriptions and the archaeological contexts at Lefkandi, Kerameikos, and Hasanlū, whereas no Phoenician ivory has yet been found in a $9^{\text {th }}$ century context. ${ }^{12}$

If we understand style with Feldman as practice that constitutes community identity, then we can explain differences between "North Syrian" and "Phoenician" ivories in terms of historical contingency. Feldman (2014: 77-78, 179) convincingly proposes that while the discussed "North Syrian" animal markings - or “earlier early Iron Age Levantine style" - signal(s) a stronger attachments to the Late Bronze Age, (which can be understood as harking back to a long-gone golden age), the strongly Egyptianizing "Phoenician” ivories or "later early Iron Age Levantine style" - could signal the embodiment of new social practices that may have been triggered by the extension of the Assyrian empire and may point to an aesthetic reaction to the Assyrian encroachment by falling back on an old neighbor and new ally. Parallel to style, I would add also shifts with regard to objects types and techniques: the small ivory objects, which stand in Late Bronze Age tradition, gradually recede in favor of furniture decoration, and Phoenician ivories tend to be heavily inlaid in Egyptian techniques.

Above I mentioned that my probing of going back to three regional styles led to an unproportionally large South Syrian group by comparison with North Syrian and Phoenician ivories and, in turn, to my suspicion that the stylistic differences may be differences in time rather than in space. This possibility gains force with Feldman's new perspective. Egyptianizing details, such as hairstyles and attire of anthropomorphic figures and hybrid creatures, predominate South Syrian ivories. Their rendering is often somewhat corrupted

12 Similarly, Wicke (2013: 565-567). 
compared to Phoenician or Egyptian prototypes. This, together with the above-suggested imitations of Phoenician prototypes, may suggest that South Syrian ivories were either contemporary with or slightly later in time than the latter. The stylistic clusters resulting from Amy Gansell's machine-learning analysis of a sample of female figures suggest that South Syrian ivories are more closely related to Phoenician than North Syrian ivories (Gansell et al. 2014). Arianna Cinquatti (in this volume) reaches similar conclusions. If we can interpret the differences between the original regional styles in terms of time rather than space, then the closeness of "South Syrian" to "Phoenician" ivories could imply that they were contemporary with the latter and, on a further step, that the Levantine manufacture of ivories boomed in the later part of the early Iron Age, probably in the $8^{\text {th }}$ century. This supposed boom in the production and consumption of Egyptianizing Levantine prestige items would then coincide with the period of Assyria's most fierce aggression, which led to the eradication of most Levantine states by the end of that century.

\section{Conclusions}

I fully agree with Marian Feldman that we should abandon the "style-geography association, typically married to linguistic affiliation" with regard to Iron Age Levantine art (Feldman 2014: 178). To see stylistic groupings as the product and contributor to potentially fluid communities of practice generates new perspectives that have the potential of explaining Levantine art in its socio-cultural context. I believe that we will never attain a comprehensive stylistic classification of Iron Age Levantine ivories due to too many unknowns and too many blurring boundaries. This, however, does not mean that we should abandon stylistic groupings altogether. I hope that future research will take into account the complex interrelations between style and society and benefit from new perspectives that go beyond mere attribution.

Acknowledgement: I am grateful to Marian Feldman and Georgina Herrmann for reading a draft of this contribution, and to Renée Steffen for stimulating discussions on Pierre Bourdieu's work.

\section{References}

Affanni, G. (2009): Ivory Sphinxes of North Syrian Tradition: The Flame and Frond School. In: S.M. Cecchini et al. (ed.), Syrian and Phoenician Ivories of the Early First Millennium BCE: Chronology, Regional Styles and Iconographic Repertories, Patterns of Inter-regional Distribution: Acts of the International Workshop Pisa, December $9^{\text {th }}-11^{\text {th }} 2004$ (Ricerche di archeologia del Vicino Oriente 3), Pisa, 171-185.

Barnett, R.D. (1957): A Catalogue of the Nimrud Ivories with Other Examples of Ancient Near Eastern Ivories in the British Museum, London.

Barnett, R.D. (1982): Ancient Ivories in the Middle East (Qedem 14), Jerusalem.

Bourdieu, P. (1990): The Logic of Practice, Cambridge.

Buhl, M.-L. / P.J. Riis (1990): Hama, fouilles et recherches de la Fondation Carlsberg 1931-1938, vol. II/2: Les objets de la période dite syro-hittite (âge du fer), Copenhagen.

Caubet, A. (2013): Working Ivory in Syria and Anatolia in the Late Bronze-Iron Age. In: K.A. Yener (ed.), Across the Border: Late Bronze-Iron Age Relations between Syria and Anatolia, Leuven, 449-463.

Cecchini, S.M. et al. (ed.) (2009): Syrian and Phoenician Ivories of the Early First Millennium BCE: Chronology, Regional Styles and Iconographic Repertories, Patterns of Inter-regional Distribution: Acts of the International Workshop Pisa, December $9^{\text {th }}-11^{\text {th }} 2004$ (Ricerche di archeologia del Vicino Oriente 3), Pisa.

Crowfoot, J.W. / G.M. Crowfoot (1938): Early Ivories from Samaria, London.

Di Paolo, S. (2009): What Production Model Can Be Deduced for First-Millennium BC Syro-Phoenician Ivories? Some Observations with Analogies Drawn from Byzantine, Early Medieval and Gothic Material. In: S.M. Cecchini et al. (ed.), Syrian and Phoenician Ivories of the Early First Millennium BCE: Chronology, Regional Styles and Iconographic Repertories, Patterns of Inter-regional Distribution: Acts of the International Workshop Pisa, December $9^{\text {th }}-11^{\text {th }} 2004$ (Ricerche di archeologia del Vicino Oriente 3), Pisa, 133-153.

Di Paolo, S. (2014): The Historiography of the Concept of 'Workshop' in Ancient Near Eastern Archaeology: Descriptive Models and Theoretical Approaches (Anthropology vs. Art History). In: B.A. Brown / M.H. Feldman (ed.), Critical Approaches to Ancient Near Eastern Art, Boston, 111-132. 
Ebitz, D. (1988): Connoisseurship as Practice, Artibus et Historiae 9, 207-212.

Feldman, M.H. (2012): The Practical Logic of Style and Memory in Early First Millennium Levantine Ivories. In: J. Maran / P.W.

Stockhammer (ed.), Materiality and Social Practice: Transformative Capacities of Intercultural Encounters, 0xford, 198-212.

Feldman, M.H. (2014): Communities of Style: Portable Luxury Arts, Identity, and Collective Memory in the Iron Age Levant, Chicago.

Finkelstein, I. (2013): The Forgotten Kingdom: The Archaeology and History of Northern Israel, Atlanta.

Gansell, A.R. et al. (2014): Stylistic Clusters and the Syrian/South Syrian Tradition of First-Millennium BCE Levantine Ivory Carving: A Machine Learning Approach, JArS 44, 194-205.

Gunter, A.C. (2009): Greek Art and the Orient, Cambridge.

Herrmann, G. (1986): Ivories from Nimrud (1949-1963) IV: Ivories from Room SW37, Fort Shalmaneser, London.

Herrmann, G. (1992): Ivories from Nimrud (1949-1963) V: The Small Collections from Fort Shalmaneser, London.

Herrmann, G. (2005): Naming, Defining, Explaining: A View from Nimrud. In: C.E. Suter / C. Uehlinger (ed.), Crafts and Images in Contact: Studies in Eastern Mediterranean Art of the First Millennium BCE (OBO 210), Fribourg, 11-21.

Herrmann, G. (2008): The Ivories from Nimrud. In: J. Curtis et al. (ed.), New Light on Nimrud: Proceedings of the Nimrud Conference (11-13 March 2002, London), London, 225-232.

Herrmann, G. / S. Laidlaw (2009): Ivories from Nimrud (1949-1963) VI: Ivories from the North West Palace (1845-1992), London.

Herrmann, G. / S. Laidlaw (2013): Ivories from Nimrud (1949-1963) VII: Ivories from Rooms SW11/12 and T10, Fort Shalmaneser, London.

Kantor, H.J. (1956): Syro-Palestinian Ivories, JNES 15, 153-174.

Karageorghis, V. (1973): Salamis 5: Excavations in the Necropolis of Salamis III, Nicosia.

Mallowan, M.E.L. / G. Herrmann (1974): Ivories from Nimrud (1949-1963) III: Furniture from SW7, Fort Shalmaneser, London.

Mazzoni, S. (2009): Ivories and Art Traditions in the Hama Region. In: S.M. Cecchini et al. (ed.), Syrian and Phoenician Ivories of the Early First Millennium BCE: Chronology, Regional Styles and Iconographic Repertories, Patterns of Inter-regional Distribution: Acts of the International Workshop Pisa, December $9^{\text {th }}-11^{\text {th }} 2004$ (Ricerche di archeologia del Vicino Oriente 3), Pisa, 107-132.

Mazzoni, S. (2014): The Aramean States during the Iron Age II-III Periods. In: M.L. Steiner / A.E. Killebrew (ed.), The Oxford Handbook of the Archaeology of the Levant c. 8000-332 BCE, Corby, 683-705.

Neer, R. (2005): Connoisseurship and the Stakes of Style, Critical Inquiry 32, 1-26.

Niemeyer, H.G. (2004): The Phoenicians and the Birth of a Multinational Mediterranean Society. In: R. Rollinger / C. Ulf (ed.), Commerce and Monetary Systems in the Ancient World: Means of Transmission and Cultural Interaction, Stuttgart, 245-256.

Orthmann, W. (2002): Die Bildkunst im Übergang von der Großreichszeit zur späthethitischen Periode. In: E.A. Braun-Holzinger / H. Matthäus (ed.), Die nahöstlichen Kulturen und Griechenland an der Wende vom 2. zum 1. Jahrtausend v. Chr.: Kontinuität und Wandel von Strukturen und Mechanismen kultureller Interaktion, Möhnesee, 153-159.

Orthmann, W. (2013): Stone Sculpture of the Iron Age in Northern Syria. In: W. Orthmann et al. (ed.), Archéologie et histoire de la Syrie I: La Syrie de l'époque néolithique à l'âge du fer (SVA 1/1), Wiesbaden, 525-542.

Poulsen, F. (1912): Der Orient und die frühgriechische Kunst, Leipzig.

Scigliuzzo, E. (2005): The ‘Wig and Wing Workshop’ of Iron Age Ivory Carving, UF 37, 557-607.

Scigliuzzo, E. (2009): A Group of Ivory Fan-Handles from the Burnt Palace of Nimrud and the 'Wig and Wing Workshop.' In: S.M. Cecchini et al. (ed.), Syrian and Phoenician Ivories of the Early First Millennium BCE: Chronology, Regional Styles and Iconographic Repertories, Patterns of Inter-regional Distribution: Acts of the International Workshop Pisa, December $9^{\text {th }}$ $11^{\text {th }} 2004$ (Ricerche di archeologia del Vicino Oriente 3), 209-237.

Suter, C.E. (2005): Discussion and Future Perspectives. In: C.E. Suter / C. Uehlinger (ed.), Crafts and Images in Contact: Studies in Eastern Mediterranean Art of the First Millennium BCE (OBO 210), Fribourg, 391-395.

Suter, C.E. (2010): Luxury Goods in Ancient Israel: Questions of Consumption and Production. In: P. Matthiae et al. (ed.), Proceedings of the $6^{\text {th }}$ International Congress on the Archaeology of the Ancient Near East (5-10 May 2008, Rome), vol. 1, Wiesbaden, 993-1002.

Uehlinger, C. (2005): Die Elfenbeinschnitzereien von Samaria und die Religionsgeschichte Israels: Vorüberlegungen zu einem Forschungsprojekt. In: C.E. Suter / C. Uehlinger (ed.), Crafts and Images in Contact: Studies in Eastern Mediterranean Art of the First Millennium BCE (ОВO 210), Fribourg, 149-186.

Wicke, D. (1999): Altorientalische Pferdescheuklappen, UF 31, 803-852.

Wicke, D. (2005): 'Roundcheeked and Ringletted': Gibt es einen nordwestsyrischen Regionalstil in der altorientalischen Elfenbeinschnitzerei? In: C.E. Suter / C. Uehlinger (ed.), Crafts and Images in Contact: Studies in Eastern Mediterranean Art of the First Millennium BCE (OBO 210), Fribourg, 67-106.

Wicke, D. (2009): 'Intermediate Tradition' - dreifach problematisch. In: S.M. Cecchini et al. (ed.), Syrian and Phoenician Ivories of the Early First Millennium BCE: Chronology, Regional Styles and Iconographic Repertories, Patterns of Inter-regional Distribution: Acts of the International Workshop Pisa, December $9^{\text {th }}-11^{\text {th }} 2004$ (Ricerche di archeologia del Vicino Oriente 3), 239-284.

Wicke, D. (2010): Kleinfunde aus Elfenbein und Knochen aus Assur (WVDOG 131), Wiesbaden.

Wicke, D. (2013): Elfenbeinschnitzereien in der Eisenzeit. In: W. Orthmann et al. (ed.), Archéologie et histoire de la Syrie I: La Syrie de l'époque néolithique à l'âge du fer (SVA 1/1), Wiesbaden, 549-570. 
Winter, I.J. (1975): North Syria in the Early First Millennium B.C., with Special Reference to Ivory Carving, PhD diss., Columbia University.

Winter, I.J. (1976a): Phoenician and North Syrian Ivory Carving in Historical Context: Questions of Style and Distribution, Iraq 38, $1-22$

Winter, I.J. (1976b): Carved Ivory Furniture Panels from Nimrud: A Coherent Subgroup of the North Syrian Style, MMAJ 11, 25-54. Winter, I.J. (1976c): Review of M.E.L. Mallowan / G. Herrmann, Furniture from SW 7 Fort Shalmaneser, London 1974, AJA 80, 201-203.

Winter, I.J. (1981): Is There a South Syrian Style of Ivory Carving in the Early First Millennium BC?, Iraq 43, $101-130$.

Winter, I.J. (1989): North Syrian Ivories and Tell Halaf Reliefs: The Impact of Luxury Goods upon 'Major Arts'. In: A. Leonard /

B.B. Williams (ed.), Essays in Ancient Civilization presented to Helene J. Kantor (SAOC 47), Chicago, 321-337.

Winter, I.J. (1992): Review of G. Herrmann, Ivories from Room 37 Fort Shalmaneser, London 1986, JNES 51, $135-141$.

Winter, I.J. (1998): Review of G. Herrmann, The Small Collections from Fort Shalmaneser, London 1992, JNES 57, $150-153$.

Winter, I.J. (2005): Establishing Group Boundaries: Toward Methodological Refinement in the Determination of Sets as a Prior Condition to the Analysis of Cultural Contact and/or Innovation in First Millennium BCE Ivory Carving. In: C.E. Suter /

C. Uehlinger (ed.), Crafts and Images in Contact: Studies in Eastern Mediterranean Art of the First Millennium BCE (OBO 210), Fribourg, 23-42. 